Penelitian

\title{
Desain Primer Berdasarkan Gen Mt-12s Rrna untuk Mendeteksi Cemaran Daging Babi pada Produk Olahan Asal Daging Sapi dengan Metode Multipleks-Pcr
}

\author{
Designed Primers Based on Mt-12s rRNA Gene to Detect the Adulteration \\ of Pork in Beef Product Using Multiplex-PCR Method
}

\author{
Yeremia Yobelanno Sitompul ${ }^{1 *}$, Sidna Artanto $^{2}$ \\ 'Departemen Klinik Reproduksi Patologi dan Nutrisi, Fakultas Kedokteran Hewan, \\ Universitas Nusa Cendana, Jl. Adisucipto - Kotak Pos 104, Kupang \\ ${ }^{2}$ Departemen Mikrobiologi, Fakultas Kedokteran Hewan, Universitas Gadjah Mada, \\ Jl. Fauna 2, Karangmalang, Yogyakarta \\ *Penulis untuk korespondensi: yeremia.sitompul@staf.undana.ac.id \\ Diterima 12 Maret 2020, Disetujui 27 Mei 2020
}

\begin{abstract}
ABSTRAK
Kasus pencampuran daging babi pada produk olahan asal daging sapi yang meresahkan masyarakat, terutama yang beragama Islam, masih ditemukan di Indonesia. Metode multipleks Polymerase Chain Reaction (multipleks-PCR) dapat mendeteksi cemaran daging babi pada produk olahan asal daging sapi. Metode ini menggunakan beberapa primer spesifik yang dapat mengamplifikasi beberapa target DNA dalam satu kali reaksi. Penelitian ini bertujuan untuk mendesain primer spesifik untuk digunakan dalam mendeteksi cemaran daging babi pada produk olahan daging sapi menggunakan metode multipleks-PCR. Pertama-tama, primer didesain secara in silico menggunakan perangkat lunak bioinformatika MegAlign, Seqbuilder, dan AmplifX. Desain ini menggunakan genmt-12s rRNA sebagai dasarnya. Primer yang didesain berupa dua primer forward untuk sapi: 5'-AGATTCACTGCATCTAACCCT-3' dan babi: 5'CTACATAACAATACCCACCATACG-3', serta satu primer reverse universal untuk sapi dan babi: 5'CCAAGCACACTTTCCAGTATG-3' Amplikon yang terbentuk secara in silico dari primer tersebut untuk DNA sapi 91 bp, sementara pada babi sebesar 230 bp. Selanjutnya, primer diuji untuk mengamplifikasi DNA daging sapi, daging babi, campuran kedua daging, dan produk olahan asal daging sapi, yaitu bakso sebanyak dua belas sampel. Hasil penelitian ini menunjukkan bahwa primer hasil pendesainan dapat digunakan untuk mengamplifikasi target DNA dari daging sapi, daging babi, campuran kedua daging, dan produk olahan. Dengan demikian, primer hasil pendesainanini terbukti dapat digunakan dalam metode multipleks-PCR untuk mendeteksi cemaran daging babi pada produk olahan sapi.
\end{abstract}

Kata kunci: primer, multipleks-PCR, daging sapi, daging babi, mt-12s rRNA

\begin{abstract}
The case of adulteration of pork in beef products, which causes fretfulness especially for muslims, is still found in Indonesia. Multiplex Polymerase Chain Reaction (multiplex-PCR) is able to detect the adulteration of pork in beef products. This method uses multiple specific primers to amplify several targeted DNA mixture in single step reaction. This study aimed to design specific primers that can be utilized to detect the adulteration of pork in beef products using multiplex-PCR method. Firstly, primers were designed in silico using bioinformatic tools which were MegAlign, Seqbuilder, and AmplifX. This design was based on mt-12s rRNAgene. The designed primers were two forward primers, which are 5'-AGATTCACTGCATCTAACCCT-3' for cow and 5'-CTACATAAGAATACCCACCATACG-3' for pig, and one universal reverse primer for both animals: 5'-CCAAGCACACTTTCCAGTATG-3'. The length of amplified fragment using the designed primers for cow was $91 \mathrm{bp}$, whereas the pig was $230 \mathrm{bp}$. Secondly, the designed primers were tested to amplify DNA of cow and pig from raw beef, pork, mixture of beef and pork, and twelve samples of their products (meatballs). The result showed that the designed primers could amplify the targeted DNA specifically from raw beef, pork, mixture of both meat, and their products. Therefore, the designed primers evidently can be used to detect adulteration of pork in beef by multiplex-PCR method.
\end{abstract}

Keywords: primer, multiplex-PCR, beef,pork, mt-12s rRNA 


\section{PENDAHULUAN}

Berdasarkan Peraturan Pemerintah Nomor 28 Tahun 2004 (Anonim, 2004), bahan pangan dan produk olahan asal hewan yang beredardi masyarakat harus memenuhi berbagai standar dan ketentuan untuk mencegah pangan dari kemungkinan adanya cemaran biologis, kimia, atau benda lain yang mengganggu, merugikan, dan membahayakan kesehatan konsumen. Pemerintah menetapkan aturan bahan pangan dan produk olahan asal hewan yang beredar di masyarakat harus memenuhi persyaratan ASUH, yaitu aman, sehat, utuh, dan halal. Peningkatan permintaan konsumsi daging terutama daging sapi di masyarakat yang tidak mampu diimbangi dengan peningkatan produksi daging sapi memicu kenaikan harga daging sapi. Keadaan tersebut menyebabkan maraknya pemalsuan dan pencampuran daging sapi dengan daging lainnya terutama daging babi pada produk olahan. Pemalsuan ini sering dilakukan, karena harga daging babi yang relatif lebih murah dibanding daging sapi, serta mudah untuk memalsukan kedua daging ini karena kemiripan bentuk fisik kedua daging yang cenderung susah dibedakan oleh orang awam (Ali et al., 2012). Isu ini tentu saja melanggar persyaratan keamanan pangan ASUH, terutama pada aturan utuh dan halal. Metode deteksi dan identifikasi jenis hewan yang digunakan sebagai bahan pangan menjadi sangat penting untuk mengetahui keaslian produk dan menjamin keamanan pangan yang beredar di masyarakat.

Multipleks Polymerase Chain Reaction (multipleks$P(R)$ merupakan metode deteksi berbasis Deoxyribonulceic Acid (DNA) dan modifikasi dari metode PCR konvensional yang menggunakan beberapa set primer secara bersamaan dalam mengamplifikasi beberapa daerah target dalam satu kali reaksi. Metode deteksi ini dapat dikatakan cukup akurat dan cepat dalam mendeteksi jenis hewan dari daging yang digunakan. Penggunaan molekul DNA mitokondria sebagai dasar pendesainan primer dalam metode multipleks-PCR lebih direkomendasikan dibandingkan dengan DNA nukleus karena jumlah DNA mitokondria berkali-kali lipatlebih banyak dalam satu sel yang sama dan memiliki spesifisitas yang tinggi untuk tiap spesies karena hanya diturunkan dari DNA induk betina (Galtier et al., 2009; Butler, 2011). Beberapa penelitian telah dipublikasikan menggunakan primer berdasarkan gen DNA mitokondria seperti gen ribosomal RNA yaitu mt-12s rRNA, dikombinasikan dengan primer berdasarkan gen DNA mitokondria lainnya seperti gen $16 \mathrm{~s}$ rRNA dan tRNAVal dalam metode multipleks-PCR untuk mengidentifikasi ada tidaknya cemaran daging babi dari berbagai daging (Dalmasso et al., 2004; loja-Boldura et al., 2011; Sakalar dan Abasiyanik, 2011). Cahyadi et al. (2018) telah mendesain primer menggunakan gen mt-12s rRNA sebagai dasar pendesainan primer untuk identifikasi sapi, babi, dan ayam dengan multipleks-PCR, namun belum sampai dalam penggunaan untuk identifikasi kandungan daging pada suatu produk olahan.

Penelitian ini bertujuan untuk mendesain primer spesifik berdasarkan urutan basa gen mt-12S rRNA sapi dan babi dan mengaplikasikannya dalam mendeteksi adanya cemaran daging babi dalam produk olahan asal daging sapi menggunakan metode multipleks-PCR.

\section{BAHAN DAN METODE}

Sampel yang digunakan untuk uji spesifitas primer berasal dari daging sapi dan daging babi yang dijual di supermarket Superindo, Yogyakarta. Sampel bakso yang digunakan untuk uji terapan berasal dari 12 warung makan bakso yang dijual di beberapa lokasi daerah kota Yogyakarta. Sumber daging yang digunakan sebagai bahan bakso yang dijadikan sampel uji terapan disajikan pada Tabel 1.

\section{Pendesainan Primer Secara in Silico}

Desain primer secara in silico dibuat berdasarkan data gen mt-12s rRNA babi dan sapi yang didapat dari data sekuens gen mt-12s rRNA babi dan sapi pada GenBank, masing-masing sebanyak 15 data. Nomor akses GenBank untuk DNA Sapi yang digunakan:

Tabel 1 Data sumber daging yang digunakan sebagai bahan pembuatan bakso

\begin{tabular}{cc}
\hline Bakso & Sumber Daging* \\
\hline 1 & Sapi \\
2 & Sapi \\
3 & Sapi \\
4 & Sapi \\
5 & Sapi \\
6 & Sapi \\
7 & Sapi \\
8 & Sapi \\
9 & Sapi \\
10 & Ayam \\
11 & Sapi \\
12 & Babi \\
\hline
\end{tabular}

*) Data sumber daging berasal dari informasi yang diberikan oleh penjual 
JN817311.1, JN817312.1, JN817320.1, JN817329.1, KF163064.1, KF163094.1, JN817350.1, JN817351.1, JN817331.1, JN817332.1, AF492351.1, JN817342.1, JN817344.1, JN817347.1, JN817349.1, dan HQ 025805.1 . Nomor akses GenBank untuk DNA Babi: AY574045.1, EF545591.1, EF545583.1, EF545576.1, AY337045.1, AY574046.1, EF545588.1, FJ236991.1, EU 090703.1, DQ207753.1, AY574048.1, EF545581.1, EF545567.1, EF545574.1, dan EF545577.1. Data-data ini dikonsensus menjadi satu DNA yang selanjutnya di-alignment dan dianalisis menggunakan perangkat lunak MegAlign dan SeqBuilder. Uji PCR dilakukan secara in silico menggunakan primer hasil analisis DNA konsensus sapi dan babi menggunakan perangkat lunak AmplifX.

\section{Isolasi DNA}

Isolasi DNA dari daging sapi dan babi serta 12 sampel bakso menggunakan Genomic DNA mini Kit for Tissue produksi Geneaid yang berisi buffer, GBT buffer, W1 buffer, wash buffer, elution buffer, proteinase K dan GD column. Prosedur isolasi sesuai dengan prosedur dari Genomic DNA mini Kit for Tissue produksi Geneaid, sampel DNA hasil isolasi disimpan pada suhu $-20^{\circ} \mathrm{C}$.

\section{Multipleks-PCR}

Molekul DNA hasil isolasi dari daging sapi dan babi, serta dua belas sampel bakso digunakan sebagai template DNA dalam proses amplifikasi dengan metode multipleks-PCR untuk uji spesifitas primer dan uji terapan. Amplifikasi DNA template menggunakan primer hasil pendesainan yang diperoleh dari Integrated DNA Technologies (IDT) yang berkode BTF, SSF, dan RU. Komposisi campuran pereaksi multipleks-PCR untuk tiap DNA dalam satu reaksi sebanyak $25 \mu \mathrm{l}$ adalah $12,5 \mu \mathrm{l}$ KAPA 2G Fast multiplex-PCR Kit, $1 \mu \mathrm{l} 10$ pmol untuk masing-masing primer forward BTF dan SSF, $2 \mu \mathrm{l} 10$ pmol primer reverse $\mathrm{RU}, 5 \mu \mathrm{l}$ template DNA dan ditambahkan air pelarut (Molecular Grade Water) untuk memenuhi volume satu reaksi hingga mencapai $25 \mu \mathrm{l}$. Khusus untuk DNA campuran sapi dan babi (1:1) pada uji spesifitas primer menggunakan komposisi $5 \mu$ template DNA yang terdiri dari 2,5 $\mu$ l DNA template sapi dan 2,5 $\mu \mathrm{l}$ template DNA babi. Pelaksanaan amplifikasi dilakukan sesuai dengan prosedur Fast multiplex-PCR menggunakan metode Low Plex dengan program: predenaturasi pada suhu $95^{\circ} \mathrm{C}$ selama 3 menit, denaturasi pada $95^{\circ} \mathrm{C}$ selama 15 detik suhu annealing pada suhu $60^{\circ} \mathrm{C}$ selama 30 detik, polimerisasi pada suhu $72^{\circ} \mathrm{C}$ selama 30 detik, dan elongasi pada suhu $72^{\circ} \mathrm{C}$ selama 10 menit. Reaksi dilakukan sebanyak 30 siklus.

\section{Elektroforesis}

Amplikon yang terbentuk dari proses multipleksPCR tersebut dielektroforesis menggunakan gel agarose dengan konsentrasi $1 \%$. Komposisi untuk satu sumuran adalah amplikon sebanyak $8 \mu \mathrm{L}$ dicampurkan dengan $2 \mu \mathrm{L}$ loading buffer (BlueJuice) hingga homogen. Campuran ini dimasukkan ke dalam sumuran gel agarose yang diletakkan di dalam tangki elektroforesis yang berisi larutan TBE buffer 1X. Elektroforesis dilakukan dengan arus listrik 100 volt selama 30 menit. Pita molekul DNA yang terbentuk hasil elektroforesis ini diamati dengan bantuan UV transiluminator. Panjang DNA hasil amplifikasi dapat diketahui dengan DNA Marker yang berukuran $100 \mathrm{bp}$.

\section{HASIL}

\section{Desain Primer}

Berdasarkan hasil analisis urutan basa data sekuen gen mt-12s rRNA sapi dan babi dari data GenBank secara in silico untuk lokasi primer, set primer yang digunakan terdiri dari dua primer forward spesifik dan satu primer reverse universal untuk sapi dan babi. Lokasi masing-masing primer forward berada pada daerah gen mt-12s rRNA yang memiliki varian tinggi. Pemilihan lokasi primer reverse universal terletak pada daerah gen mt-12s rRNA yang homolog untuk kedua spesies, yaitu mendekati ujung 3'. Data sekuen gen mt-12s rRNA sapi dan babi dan lokasi penempelan primer disajikan pada Gambar 1.

Berdasarkan jarak antara lokasi urutan basa primer forward sapi dan babi terhadap primer reverse universal, proses amplifikasi menggunakan primer-primer tersebut akan menghasilkan ukuran amplikon secara berturut-turut untuk sapi dan babi $91 \mathrm{bp}$ dan $230 \mathrm{bp}$. Kualitas urutan basa primer hasil pendesainan disajikan data penilaian kriteria desain primer pada Tabel 2.

Secara in silico, primer-primer yang didesain mampu mengamplifikasi secara spesifik. Amplifikasi menggunakan primer forward sapi dan primer reverse universal terhadap DNA sapi yang telah dikonsensus menghasilkan amplikon sebesar 91 bp dan 


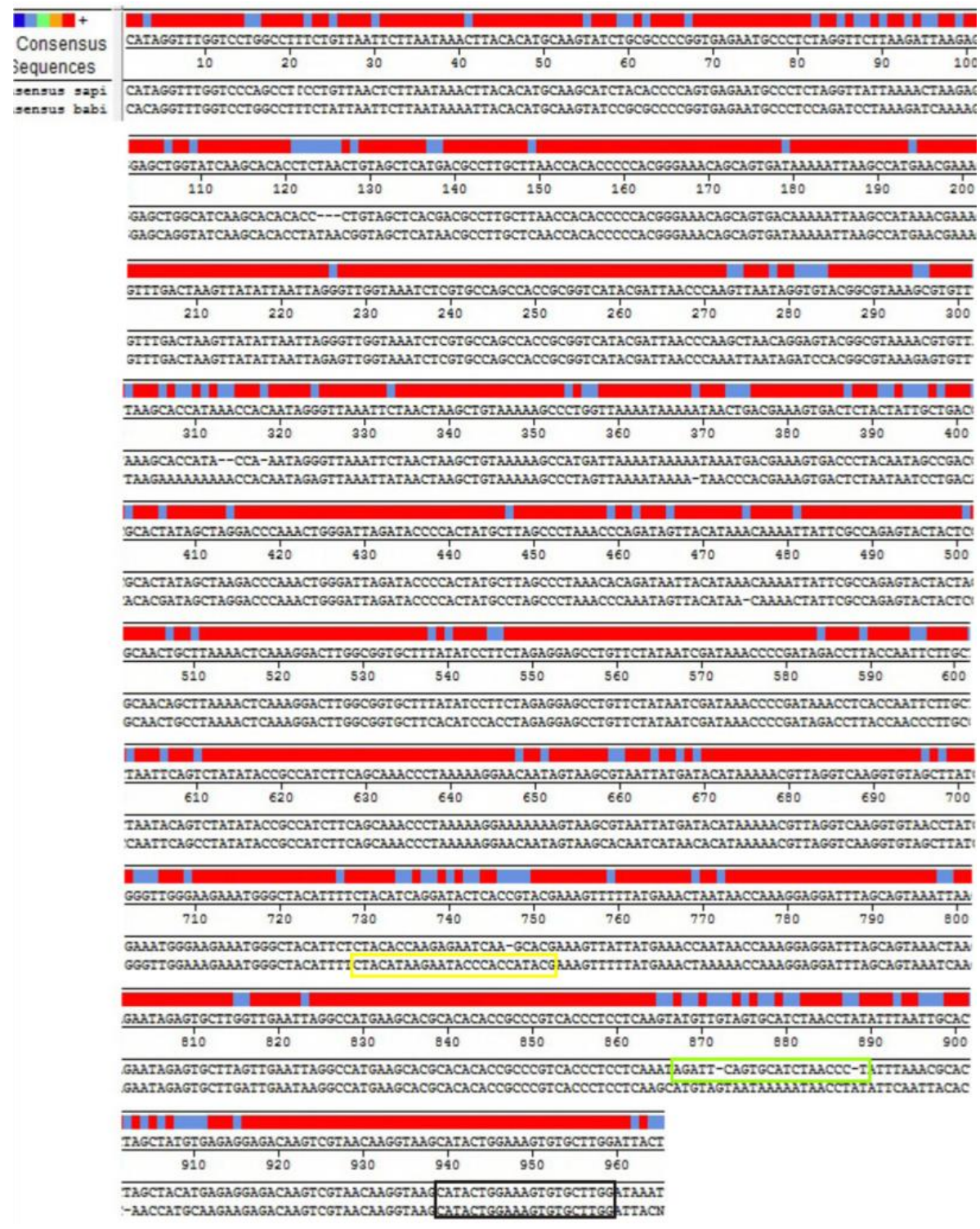

Gambar 1 Lokasi penempelan primer pada gen mt-12s rRNA sapi dan babi. Warna merah: Daerah homolog; Warna Biru: daerah variasi; Urutan basa di dalam kotak kuning: Lokasi penempelan primer forward babi (729-752); Urutan basa di dalam kotak hijau: Lokasi penempelan primer forward sapi (867-889); Urutan basa di dalam kotakhitam: Lokasi penempelan primer reverse universal (939-959)

tidak terbentuk amplikon ketika menggunakan DNA babi sebagai template DNA. Begitu juga sebaliknya, pengunaan primer forward babi dan primer reverse universal dapat mengamplifikasi DNA babi dengan menghasilkan amplikon sebesar $230 \mathrm{bp}$, sementara amplifikasi terhadap DNA sapi tidak menghasilkan amplikon.

\section{Uji Spesifitas Multipleks-PCR}

Selanjutnya, primer hasil pendesainan diuji spesifitasnya dengan mengamplifikasi DNA hasil isolasi dari daging sapi dan babi dengan metode multipleks-PCR secara in vitro sebagai pembuktian kemampuan primer hasil pendesainan secara in silico. Hasil pengujian spesifitas primer terhadap masing-masing DNA murni dan satu sampel kombinasi antar DNA murni terdapat di Gambar 2.

Gambar 2 menunjukkan bahwa pada DNA sapi $(\mathrm{S}+)$ dan babi $(\mathrm{B}+)$ yang diuji masing-masing terbentuk satu pita dengan ukuran $91 \mathrm{bp}$ dan $230 \mathrm{bp}$. Sampel DNA campuran sapi dan babi yang diuji membentuk dua pita dengan ukuran 91 bp dan 230 bp, sejajar dengan pita pada sumuran $\mathrm{S}+$ dan $\mathrm{B}+$. Ukuran yang terbentuk dari uji spesifitas ini sesuai dengan ukuran amplikon yang terbentuk pada uji PCR secara in silico, yaitu 91 bp pada DNA sapi dan 230 bp pada DNA babi. 
Tabel 2 primer forward sapi, primer forward babi, dan primer reverse universal pada gen mt-12s rRNA sapi dan babi

\begin{tabular}{|c|c|c|c|}
\hline Kriteria & Primer Forward Sapi & Primer Forward Babi & $\begin{array}{l}\text { Primer Reverse } \\
\text { Universal }\end{array}$ \\
\hline Susunan basa & $\begin{array}{l}\text { 5'AGATTCACTGCATCTAA } \\
\text { CCCT-3' }\end{array}$ & $\begin{array}{l}\text { 5'-CTACATAAGAATACC } \\
\text { CACCATACG-3' }\end{array}$ & $\begin{array}{l}\text { 5'-CCAAGCACACTTT } \\
\text { CCAGTATG-3' }\end{array}$ \\
\hline Panjang Nukleotida (bp) & 21 & 24 & 21 \\
\hline $\operatorname{Tm}\left({ }^{\circ} \mathrm{C}\right)$ & 52 & 52 & 53 \\
\hline $\begin{array}{l}\text { Kandungan } \mathrm{G}+\mathrm{C}(\%) \\
\text { Primer-dimer }\end{array}$ & $\begin{array}{l}42 \\
\text { Tidak ada }\end{array}$ & $\begin{array}{l}41 \\
\text { Tidak ada }\end{array}$ & $\begin{array}{l}47 \\
\text { Tidak ada }\end{array}$ \\
\hline Stabilitas Ujung 3' & stabil & stabil & stabil \\
\hline
\end{tabular}

\section{Uji Terapan Multipleks-PCR}

Pengujian primer hasil pendesainan dengan metode multipleks-PCR selanjutnya diaplikasikan dalam identifikasi kandungan daging pada produk olahan asal daging berupabakso yang dijual di Yogyakarta. Hasil uji terapan divisualisasikan dengan metode elektroforesis pada gel agarose $1 \%$ dan disajikan pada Gambar 3. Hasil amplifikasi multipleks-PCR menunjukkan pada bakso 1, 2, 3, 4, dan 9 terbentuk dua pita yang masing-masing sejajar dengan pita DNA sapi dan babi berukuran 91 bp dan 230 bp. Pada bakso 5, 6, 7, 8, dan 11 terbentuk satu pita yang sejajar dengan pita DNA sapi berukuran 91 bp. Bakso 10 tidak terbentuk pita. Bakso 12 terbentuk satu pita yang sejajar dengan pita DNA babi berukuran $230 \mathrm{bp}$.

\section{PEMBAHASAN}

\section{Pendesainan Primer Secara in Silico}

Pendesainan primer secara in silico untuk multipleks-PCR dapat menghasilkan primer forward dan reverse yang bersifat spesifik untuk masing-masing spesies atau salah satu bersifat universal. Dalmasso et al. (2004) mendesain primer dimana baik primer forward dan reverse bersifat spesifik, sementara Cahyadi et al. (2018) mendesain primer bersifat universal untuk primer forward, dan primer reverse spesifik untuk tiap spesies. Berdasarkan hasil analisis urutan basa data sekuen gen mt-12s rRNA sapi dan babi dari data GenBank secara in silico untuk lokasi primer, set primer yang didesain pada penelitian ini terdiri atas dua primer forward spesifik dan satu

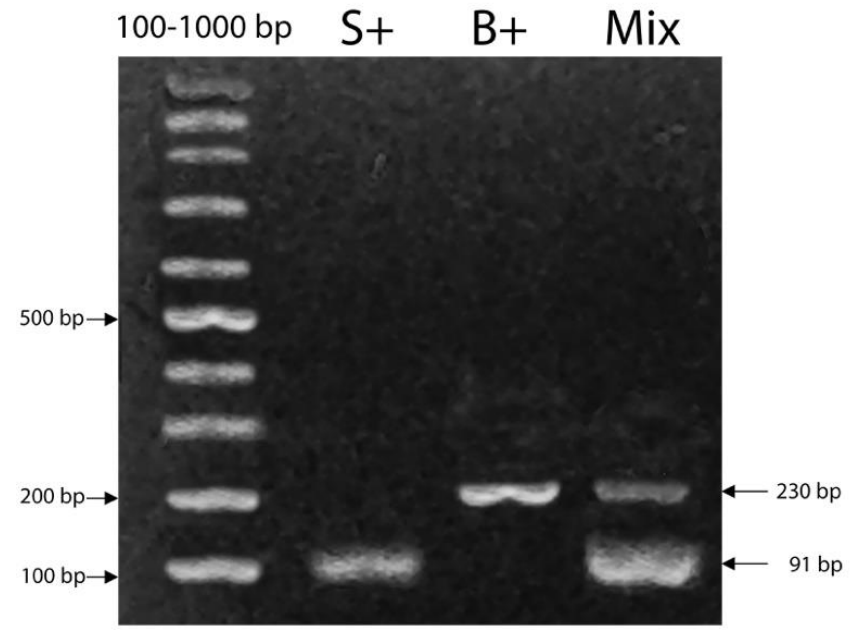

Gambar 2 Profil elektroforesis hasil amplifikasi DNA sapi, babi, dan DNA campuran sapi dan babi dengan marker DNA 100-1000 bp. S+: DNA Sapi; B+: DNA Babi; Mix: DNA Sapi + Babi

primer reverse universal untuk sapi dan babi. Lokasi masing-masing primer forward berada pada daerah gen mt-12s rRNA yang memiliki varian tinggi. Pemilihan lokasi primer reverse universal terletak pada daerah gen mt-12s rRNA yang homolog untuk kedua spesies, dimana menurut Yang et al. (2014), gen mt-12s rRNA di daerah ujung 3' memiliki kemiripan yang tinggi pada kebanyakan spesies. Menurut Edwards dan Gibbs (1994), jarak lokasi penempelan primer antara primer forward dengan primer reverse pada fragmen DNA perlu diperhatikan agar terbentuk amplikon yang ukurannya jelas teramati berbeda dan spesifik. Gambar 1 menunjukkan bahwa proses amplifikasi menggunakan primer-primer tersebut akan menghasilkan ukuran amplikon se- 


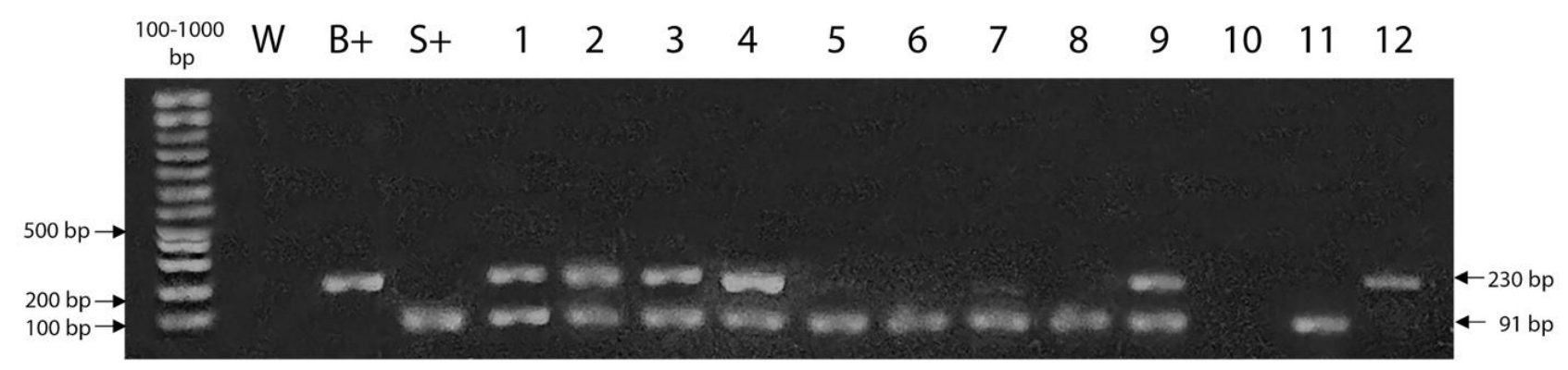

Gambar 3 Elektroforesis hasil amplifikasi 12 sampel bakso dengan marker DNA 100-1000 bp. W: Air steril (kontrol negatif); S+: DNA Sapi; B+: DNA Babi; 1-12: Sampel bakso yang diuji.

cara berturut-turut untuk sapi dan babi 91 bp dan $230 \mathrm{bp}$.

Kriteria primer hasil pendesainan yang baik adalah memiliki panjang primer antara 18-30 bp, mengandung $\mathrm{G}+\mathrm{C}$ sekitar 50\%, pada ujung 3' untuk tiap set primer tidak boleh saling berkomplementer untuk menghindari terjadinya primer-dimer, dan tidak memiliki urutan sekuen primer nukleotida $\mathrm{C}$ atau $G$ bersekuens tiga atau lebih pada ujung 3' agar tidak terjadi kesalahan ikatan pada daerah yang kaya akan seku en $\mathrm{G}+\mathrm{C}$ yang bukan merupakan lokasi fragmen DNA yang akan diamplifikasi (Lo et al., 2006). Menurut Handoyo dan Rudiretna (2000), Tm primer sebaiknya antara $50^{\circ} \mathrm{C}-65^{\circ} \mathrm{C}$ dan pada ujung $3^{\prime}$ sebaiknya tidak terdapat $\mathrm{A}$ atau $\mathrm{T}$ berurutan 2 atau lebih. Menurut Henegariu et al. (1997), kandungan $\mathrm{G}+\mathrm{C}$ yang baik sebanyak 35\%-60\%. Berdasarkan data primer pada Tabel 2, primer yang didesain pada penelitian ini telah sesuai dengan kriteria-kriteria primer tersebut. Hasil uji PCR secara in silico menggunakan perangkat lunak AmplifX menunjukkan bahwa primer yang didesain mampu mengamplifikasi DNA target secara spesifik.

\section{Uji Spesifitas dan Terapan}

Hasil pengujian spesifitas primer terhadap masing-masing DNA murni dan satu sampel kombinasi antar DNA murni pada Gambar 2 menunjukkan primer secara spesifik mampu mengamplifikasifragmen DNA dengan membentuk satu pita amplikon dengan ukuran yang spesifik dari sampel DNA murni dan membentuk dua pita dengan ukuran yang spesifik untuk dua fragmen DNA target dalam satu sampel DNA campuran. Dengan demikian, pengujian terapan penggunaan primer hasil pendesainan dapatdilakukan dengan cara mengidentifikasi asal daging pada suatu produk olahan.
Berdasarkan hasil amplifikasi multipleks-PCR pada dua belas bakso menggunakan ketiga primer ini menunjukkan daging yang digunakan pada bakso 5 , $6,7,8,10,11$, dan 12 sesuai dengan informasi penjual (Tabel 1). Amplifikasi DNA isolasi dari bakso 5, 6, 7, 8, dan 11 yang menggunakan daging sapi sebagai dasar bahan pembuatan bakso menghasilkan satu pita amplikon yang berukuran spesifik untuk DNA sapi. Amplifikasi DNA isolasi dari bakso 10 yang menggunakan daging ayam sebagai dasar bahan pembuatan bakso tidak menghasilkan amplikon. Hal ini menunjukkan bahwa primer tidak dapat mengamplifikasi DNA ayam. Amplifikasi DNA isolasi dari bakso 12 yang menggunakan daging babi sebagai dasar bahan pembuatan bakso menghasilkan satu pita amplikon yang berukuran spesifik untuk DNA babi. Amplifikasi DNA isolasi dari bakso 1, 2, 3, 4, dan 9 menghasilkan dua pita amplikon berukuran spesifik untuk DNA sapi dan DNA babi yang mengindikasikan bahwa bakso tersebut berasal dari campuran daging sapi dan babi. Ketidaksesuaian antara hasil amplifikasi dengan informasi penjual pada kelima bakso tersebut dapat diasumsikan adanya tindakan kecurangan pencampuran daging babi dengan daging sapi dalam pembuatan bakso. Perbedaan tebal dan tipis pita pada tiap bakso kemungkinan dikarenakan konsentrasi DNA yang terisolasi tidak sama. semakin kecil konsentrasi DNA, maka semakin sedikit yang teramplifikasi dan sebaliknya.

Penggunaan gen ribosomal RNA yaitu gen mt-12s rRNA sebagai dasar pendesainan primer dalam metode multipleks-PCR dalam identifikasi cemaran daging babi telah banyak digunakan. Tetapi beberapa penelitian yang telah dipublikasikan kebanyakan mengkombinasikan gen mt-12s rRNA dengan fragmen DNA mitokondria lainnya, seperti gen 16s rRNA sebagai dasar pendesainan primer (Sakalar dan Abasiyanik, 2011; Dalmasso et al., 2004). 
Cahyadi et al. (2018) telah mendesain primer untuk identifikasi sapi, babi, dan ayam dengan multipleks-PCR menggunakan gen mt-12s rRNA sebagai dasar pendesainan primer. Namun demikian, selain lokasi penempelan primer yang berbeda, primer dari penelitian ini telah teruji dapat mengamplifikasi DNA target baik yang berasal dari sampel daging mentah maupun dari produk olahan asal daging, yaitu bakso. Dua pita amplikon yang terbentuk dengan ukuran berbeda dan spesifik untuk sapi dan babi pada DNA campuran dari sampel daging mentah dan bakso yang teridentifikasi terdapat cemaran babi dalam satu kali reaksi menunjukkan primer ini mampu mengamplifikasi DNA sapi dan babi secara spesifik dalam satu tabung, sesuai prinsip metode multipleks-PCR. Tidak terbentuknya pita pada bakso yang dibuat dengan bahan dasar daging ayam menunjukkan kespesifikan dari primer hasil pendesainan dalam mengamplifikasi DNA target. Hal ini membuktikan bahwa penggunaangen mt-12s rRNA sebagai dasar pendesainan primer dalam metode multipleks-PCR dapat menjadi salah satu metode identifikasi campuran daging babi pada produk olahan asal daging sapi.

Pendesainan primer berdasarkan gen mt-12s rDNA daging sapi dan babi dalam penelitian ini secara spesifik mampu mengamplifikasi dan mendeteksi kandungan DNA daging sapi sebesar 91 bp dan babi sebesar 230 bp maupun produk olahan dengan menggunakan metode multipleks-PCR.

"Penulis menyatakan tidak ada konflik kepentingan dengan pihak-pihak yang terkait dalam penelitian ini".

\section{DAFTAR PUSTAKA}

Ali M, Mustafa S, Hashim, U, Man YC, Foo K. 2012. Nanobioprobe for the Determination of Pork Adulteration in Burger Formulations. Journal of Nanomaterials, 2012:1-7.

Anonim. 2004. Peraturan Pemerintah Republik Indonesia No. 28 Tahun 2004 Tentang Keamanan, Mutu dan Gizi Pangan. Retrieved November 20, 2019, from http://perundangan. pertanian.go.id/admin/p_pemerintah/ PP\%20No. 28\%20Tahun $\% 202004 \% 20$ Keamanan,\%20 Mutu,\%2 0\&\%20Gizi\%20Pangan.pdf

Butler J. 2011. Advanced topics in forensic DNA typing. Amsterdam: Academic Press.

Cahyadi M, Puruhita, Barido FH, Hertanto BS. 2018. Specific primer design of mitochondrial $12 \mathrm{~S}$ rRNA for species identification in raw meats. IOP Conf . Ser.:Earth Environ. Sci. 102: 012038.

Dalmasso A, Fontanella E, Platti P, Civera T, Rosati S, dan Bottero MT. 2004. A Multiplex PCR Assay for the Identification of Animal Species in Feedstuffs. Molecular and Cellular Probes 18(2):81-87.

Edwards MC, Gibbs RA. 1994. Multiplex PCR: Advantages, Development, and Applications. Genome Res. 3:S65-S75.

Galtier N, Nabholz B, Glemin S, Hurst GDD. 2009. Mitochondrial DNA as a Marker of Molecular Diversity: a Reappraisal. Molecular Ecology 18:4541-4550.

Handoyo D, Rudiretna A. 2000. Prinsip Umum dan Pelaksanaan Polymerase Chain Reaction (PCR). Unitas9(1):17-29.

Henegariu O, Heerema NA, Dlouhy SR, Vance GH, dan Vogt PH. 1997. Multiplex PCR: Critical Parameters and Step-by-Step Protocol. BioTechniques 23:504-511.

Boldura O-M, Popescu S, Bruznican S, dan Hutu I. 2011. Applicability of Multiplex PCR Assay for the Identification of Animal Species in Feedstuffs. Bulletin UAVSM Animal Sciences and Biotechnologies 68(1-2): 179-185.

Lo YMD, Chiu RWK, Chan KCA. 2006. Clinical Applications of PCR. New Jersey: Humana Press.

SakalarE, Abasiyanik MF.2011. Qualitative Analysis of Meat and Meat Products by Multiplex Polymerase Chain Reaction (PCR) Technique. African Journal of Biotechnology 10(46): 93799386.

Sambrook J, Russel DW. 2001. Molecular Cloning : A Laboratory Manual $3^{\text {th }}$ edition. New York : Cold Spring Harbor Laboratory Press.

Yang L, Tan Z, Wang D, Xue L, Guan M-X, Huang T, Li R. 2014. Species Identification Through Mitochondrial rRNA Genetics Analysis. Science Report 4:4809. 